\title{
INFLUENCE OF PARENTING STYLES ON ADOLESCENT DELINQUENCY IN DELTA CENTRAL SENATORIAL DISTRICT
}

\author{
OKORODUDU, Grace Nwamaka PhD \\ Institute of Education \\ Delta State University \\ Abraka \\ email: okorograce@gmail.com \\ okororich@yahoo.com
}

\begin{abstract}
The study investigated the influence of parenting styles on adolescents' delinquency. 404 sample sizes were used for the study. 6 research questions and 6 research hypotheses were designed and formulated for the purpose of the study. Regression statistic was used for the analyses of the study. Irrespective of gender, location and age, the results of the analyses show that lassair-faire parenting style effectively predicts adolescents' delinquency while authoritarian and authoritative did not. Parents who are positively oriented in their styles (demandingess and responsiveness) will make their adolescents socially competent and goal - directed. Parents who exerted control and monitored adolescent activities and promoted self-autonomy were found to have the most positive effects on adolescents' behaviour. Uninvolving parents and also non responsive to adolescents needs had negative impacts on their behaviour.
\end{abstract}

Key Words: Parenting Styles, Adolescents, Delinquency

\section{Introduction}

Involvement of adolescents in delinquent activities is on the increase in Nigeria. The last two decades witnessed crimes ranging from minor stealing to major robbery and killing perpetuated by teens. There has been increasing concern of the Police and the general public on the seriousness of adolescent crime and conduct problems $(\mathrm{Wu}, \mathrm{Chia}$, Lee and Lee 1998). They reported that 
juvenile delinquency rate rose from 367 to 538 per 100,000 between 1986 and 1996. They claimed that most of the juveniles arrested in 1996 were arrested for petty crimes, such as theft, with about 38 percent arrested for shoplifting and 18 percent for simple theft. The out come of their research also shows that most serious crimes, such as rioting, robbery and extortion accounted for 15 percent. Kring, Davison, Neale and Johnson (2007) indicate that the diagnostic criteria for antisocial personality disorder ADP include two major components:

i. "A pervasive pattern of disregard for the rights of others since the age of 15; and

ii. The presence of a conduct disorder before age 15 (such as truancy, running away from home, frequent lying, theft, arson and deliberate destruction of property, working only inconsistently, breaking laws, being irritable, physically aggressive, defaulting on debts, being reckless, impulsive, neglecting to plan ahead, show little regard for truth and little remorse for their misdeeds".

Eke, (2004) notes that there are two main categories of delinquent behaviours Nigerian adolescents are engaged in: criminal and status offences. The criminal offences include stealing, arson, rape, drug offences and murder, burglary, pick pocket, and armed robbery. However, she listed status offences to include: running away from home, malingering, truancy etc.

Bingham, Shope and Rachunathan (2006) identified two classes of problem behaviour as: conventional behaviours which are prescribed or encouraged by the society. Onyehalu (2003) asserted that the existence of stable and normal societies is based on acceptable ethical principles, norms and healthy values. Okorodudu and Okorodudu (2003) referred to the norms and values as desirable behaviours; while Onyehalu (2003) claims that any departure from the accepted norms by people who are not yet adult is delinquency. However, Bingham et al (2006) refers to such behaviours which are socially proscribed/prohibited as problem behaviours. Any behaviour that falls short of societal norms, values, beliefs and expectations are undesirable behaviours (Okorodudu and Okorodudu, 2003). Onyechi and Okere (2007) in 
their research identified the following as deviant behaviours exhibited frequently and persistently in the classroom: walking out on the teacher, noise making, sleeping in class, pinching, aggression, vandalism, pilfering, lies, truancy, tardiness, irresponsibility, cheating, immorality, alcoholism, use of drugs, cultism, examination malpractice etc. Boroffice (2004) believes that factors such as biological social, view of self, attitudes, beliefs, sense of his future etc., are some of the factors that predispose adolescents to unhealthy behaviours. The menace of destitute in our streets in the cities is already a social problem to the Government and the general public. Psychological tensions and emotional disturbances at home may drive the adolescents away from home or from school and have the potentials of exposing them to negative associations. Personal performances both at home and in the public may be affected (Okorodudu and Omoni, 2005).

Okorodudu and Omoni also observed that adolescents may exhibit suicidal tendencies, juvenile delinquency, vandalism, destruction of public property, maiming and murder of parents and violence against the larger society. Juvenile delinquency is noted by Ekojo and Adole (2008) as gang delinquency. The gangs delinquent are group of adolescents and youths that exhibit criminal behaviour. Several researches done on factors that precipitate delinquency among adolescents (Okorodudu and Okorodudu, 2003; Eke, 2004; Eke, 2004a, Eke, 2004b) stress that adolescence is a period of stress and storm. Eke also observed that the period is characterized by rebelliousness. This is caused by non-conducive environment. Okorodudu and Okorodudu (2003) listed environmental factors; social factors, physical factors, psychological factors; peer group influence, drug abuse and the family factor as causes of delinquency among adolescents.

Eke (2004) observes that causes of juvenile delinquency tend to find theoretical explanations in the interaction between biological, environmental and social factors. She believes that the biological or genetic make up of individuals can predispose adolescents' engagement in delinquent activities. Chromosomal abnormalities among the adolescents may predispose them to anti- 
social behaviours. The Nigerian Government had devised and employed several measures aimed at curbing adolescents' delinquency in our society but to no avail. For instance establishment and administration of juvenile justice; promulgation of juvenile laws and courts, establishment of remand homes, establishment of security and law enforcement agency etc. Many researchers agree that the foundation of adolescent delinquency is rooted in the kind of home the adolescent is brought up (Odebumi, 2007; Otuadah, 2008; Okpako, 2004; Utti, 2006). The basis for good behaviour orientation and good adolescents' attitude development is founded on positive parenting. Okpako (2004) stated that the parents should be blamed and be made to take responsibility for the misfortune that befalls the adolescents. Hence the study wishes to examine the relationship between adolescents' delinquency and parenting styles.

Edwards \& Shane (2006) emphasized the importance of extended family ties in Latino culture as well as the strong identification and attachment of individuals with tier families. In Africa, parents expand beyond immediate mother and father to include members of the extended family, neighbours and every other person who in one way or the other is involved in upbringing of the child (Okpako, 2004).

\section{Parenting Style}

Parenting has been playing very crucial roles in adolescents' transition to adulthood. Parenting has been recognized as a major vehicle in socializing the child (Utti 2006); Parenting according to Okapko, 2004; Ofoegbu , 2002, Utti, 2006 is the act of parenthood, the child upbringing, training rearing or child education. Parents world over, are in each of greener pasture, and for some decades, there has been drift of families from their place of origin to urban cities.

Inman, Howard, Beaumont \& Walker (2007) opine that parents are often faced with the complex task of parenting their children within a culture is notably dissimilar from their culture of origin. For instance, Asian Indian parenting practices typically include authoritarian parenting styles (Jambunathan \& 
Counselman, 2002; Inman et al 2007). Dysfunction homes typified by divorce or death of parents may prong adolescents into participation in delinquent behaviours (Boroffice 2004). The incidence of parental separation may result in adolescents embarrassment, depression (Boroffice 2004, Hyssong, 2000) and even make them miss school, perform poorly academically and participate in delinquent behaviours (Atkinson, 2004, Boroffice, 2004; Okorodudu, 2006). Harsh and inconsistent parenting is the main cause of conduct disorders. The persistence aspects of parental rearing styles of children which are strong discipline; parental disharmony; rejection of the child and inadequate involvement in the child's activities cause delinquency among adolescents (Okorodudu \& Okorodudu, 2003).

Some research reports have shown that a large percentage of all juvenile delinquents come from homes that lacked normal parental love and care. Attention, love and warmth go a long way in assisting the child's emotional development and adjustment (Odebumi 2007). Children at adolescence stage require parental love, care, warmth and serious attention to adjust adequately, in the environment in which he/she finds him/herself. Parents have major roles to play in the adjustment process of adolescent. The behavioural problems of most deviants are rooted in their homes (Onyechi and Okere, 2007). Otuadah (2006) noted that when the relationship between the parents and the adolescent is warm, it creates a healthy environment for the development of the adolescent. Adolescents exhibiting traits of friendliness, cheerfulness, positive emotions and good maturity traits, show evidently, that such adolescents come from homes where they are accepted and loved (Otuadah, 2006). Okpako (2004) noted that a child well brought up will remain a source of joy and happiness for such family. The neglected adolescent gradually becomes a drug addict, hardened criminal, aggressive, restive, arm robber, cultist, ritualist, rapist etc. The required parental monitoring and control (Ang \& Goh, 2006) for adolescents' development may be hindered due to parents' serious involvement in economic activities to meet up with family financial commitments. Ukoha (2003), 
Onyewadume (2004) and Otuadah (2006) observe that parents spend little or no time at home to assist in the upbringing of the children. The children invariably fall into evil association. Loromeke (1997) is of the view that parents bring up their children according to the training they also received from their own parents. For instance, majority of parents who grew up in the strict environment end up creating such for their own children. African tradition has it that the use of high control, authority and punishment bring the best out of a child.

Parenting styles are categorized under three major forms: the authoritarian, the authoritative or democratic, and the permissive or laissez-faire or self indulgence or un-involving (Baumrind, 1991). The authoritarian parenting style constitutes of parents who are often strict, harsh (Ang. \& Groh, 2006). Authoritative parents according, to Ang \& Groh, are flexible and responsive to the child's needs but still enforce reasonable standards of conduct. While permissive or laissez-faire parents are those who impose few restrictions, rules or limits on their children. Reports had shown that authoritarian parenting styles has negative connotation in literature because of the negative behaviour outcomes of adolescents and children. However, on the same, note outcome of some researches revealed that authoritarian parenting yield positive effects on Asian and Indian adolescents (Ang and Goh, 2006). Some found that authoritative parenting style has more positive effects on the adolescents' behaviour. Ang \& Groh, Utti, (2006) reported that permissive or laissez faire parenting without well defined or clear-cut goals and such parents play a passive role in the rearing of children. Utti (2006) in a research conducted on relationship between parenting styles and students' academic achievement found that laissez-faire parenting had more negative effects on the students academic achievement. Several researchers had shown that adolescents from laissez-faire parenting are more prone to delinquent behaviours and health problems than those from the other forms of parenting homes.

Umukoro, (1997, 1977, ) Otuadah (2006), Eke (2004), and Chen \& Chi (2005), -in their researches found that adolescents who are exposed to higher level of warmth, induction and monitoring 
parenting background would less likely be delinquents. Researchers notably, categorized parenting into two major and broad forms: "Demandingness" and "Responsiveness" (Ang et al, 2006 and chen et al, 2005)

Demanding and responsive are classified as authoritative parents whose children are expected to perform better in social competence than children whose parents are authoritarian (demanding but not responsive, permissive/laissez-fair responsive but not demanding (Ang et al 2006; Chen, et al 2005; Utti, 2006). Authoritative parenting (positive parenting) has positive effects on the adolescents' behaviour while authoritarian and laissez-faire (negative parenting) have negative effect. Odebunmi (2007) and Okapko (2006) identified some factors which will make for positive parenting as: provision of children's needs: good food, shelter, water, love, warmth, affection, education, control, monitoring, dialogue, supervision, etc. Stanford University News Service (415723-2558) reported that positive parenting styles have been shown to help American teenagers earn good grades, avoid delinquency, and also enhance ethnic pride in teens who are ethnic minorities. Stanford university News Service (415) 723 - 2558 citing Feldan, S. Shirley (of the Stanford Centre for the study of families, children and youths and Rosenthal, A. Doreen of the University of Melbourne in Victoria, Australia) found that adolescents whose parents exhibited warmth and control while permitting their children to express their own views are likely to express pride and positive feelings about their ethnicity. Darling (2007) reported that parenting style predicts child well-being in the domains of social competence, academic performance, psychosocial development and problem behaviour. Children and adolescents whose parents are authoritative rate themselves and are rated by objective measures as more socially and instrumentally competent than those whose parents are non-authoritative. All these will enhance and promote proper growth and development of adolescents in their environment.

However, factors which constitute negative parenting (poor parenting) were equally identified as: parental harshness, 
aggression; lack of love, lack of affection, lack of care, adequate monitoring and supervision, and lack of control to mention but a few. These and a host of other conditions may prong the adolescents into delinquent behaviours and increase in crime rate. Besides, poor parenting may enhance adolescents' health problems. For instance, Kring et al (2007) reported a clinical case of a 19 year old man with irregular breathing, a rapid pulse and dilated pupils. Diagnosed symptoms began after excessive drugs use resulting from poor and parental disharmony. Apart from addiction he was also into other delinquent activities such as: disobedience, disengagement from family activities, stealing and selling people's properties to get money for drugs and videos. Darling (2007) also observed that children and adolescents whose parents are uninvolved perform most poorly in all domains.

Based on these claims the study wants to examine the parenting style that will enhance adequate adjustment of the adolescents in the society.

\section{Gender}

Bingham et al (2006) generally observed that men had greater numbers of offence than women. The outcome of their behaviour also shows that men had lower parental monitoring and greater parental permissiveness, less parental-oriented and had more substance use than women. The greater parental permissiveness and less parental monitor must increase men's juvenile delinquency. Some researches had shown that gender is not a significant factor in adolescents' deviant behaviour and subsequent effect on academic achievement (Onyechi and Okere, 2007). Boys with poor parental background may become school dropouts who may later graduate to street boys, bus conductors or touts (area boys) found in uncompleted buildings, bridges, motor parks etc (Okpako, 2004; Otuadah 2006). Mallum, Haggai \& Ajaegbu (1999) and $\mathrm{Wu}$ et al in their research found that there was no significant difference in delinquency between the two categories, males and females. Sekuku; Rimfat and Ogbonna (2003) noted that until recently male adolescents were by far more involved in delinquent 
acts than female. But times have changed, more and more females are now getting involved in delinquent acts.

\section{Age}

There is a huge variation in age factor of adolescents from one society to another. However, age is not determined by the society (Okpako 2009) but rather by biological compositions (Ezeh, 2005). Ezeh noted that the biological changes are the driving force behind all adolescents' behaviour. Wu et' al (1998) found from their studies that increase in age of participants attracted increase in the rate of delinquency. They infer that as the adolescent grows older, he/she has more courage to try out new things; more criminal things and rebellious nature also increase. It was also found that the mean of delinquency scores from age group 15 is significantly different from that of the other age groups while the mean of delinquency scores for age groups of 12, 13, and 14 and above 16 are about the same (Wu 1998).

\section{School Location}

There is the general notion that school location may predict adolescents' delinquency. The environment influences the behaviour of adolescents (Eke, 2004). The implication of the above is that the student from rural schools would behave differently from students in urban location. But the whole wide world is a global village. The adolescent in the two categories behave in the same manner because of the availability of computer and internet services.

\section{Methods}

\section{Study overview}

This descriptive survey study embarked on determining the influence of parenting styles on the adolescents' delinquency in secondary schools in Delta Central. Three main parenting styles were identified as:

(i) Authoritarian (negative parenting which involves demanding but not responsive). The major features of this parenting style are parental harshness, violence, 
aggression, punishment, parental expectations, strict rules etc.

(ii) Permissive/laissez-faire parenting style (is also negative parenting that constitutes responsiveness but no demandingness).

The main characteristics of these styles are: parental passiveness, lack of control, lack of monitoring, lack of supervision, few rules, lack of parental expectations to mention a few.

(iii) Authoritative parenting (is positive parenting style which involves responsive and demanding). The major features of this style are: provision of the adolescent's needs, healthy relationship, provision of educational opportunities, control, monitoring, supervision, dialogue explanations etc.

The negative parenting style is likely to predict adolescents' delinquency more than positive parenting styles. Some other factors that are likely to influence the outcome of the study were also investigated, example school location, gender and age.

\section{Population and Sample}

The population of the study comprised all the secondary schools in Delta Central Senatorial District. Total number of 60 public secondary schools was in session during the period of the study. 10 schools out of the 60 public secondary schools (i.e. 16\%) were randomly selected. Kline (2005) states that increase in the sample size will make any result statistically significant. The educational system is such that the secondary school is divided into two sections. The JSS $1-3$ and the SSS $1-3$. The JSS 1 and 2, and SSS 1 and 2 classes were selected respectively for the study. Each of the classes comprised 50 students on the average. Each of the levels comprised two arms. On the whole 4,000 students comprised the population used for the study. 404 participants were randomly selected and used for the study, 5 out of 10 schools were identified as rural schools while the remaining 5 were urban. 


\section{Measures}

The purpose of the study is to determine the relationship between adolescents' delinquency and the parenting styles among secondary school students. The instruments used for the study were adolescent delinquency and parenting styles questionnaire (ADAPSQ). The instrument is divided into 3 parts. The first section solicited information on the bio-data of the participants. The items include the gender of the participants, the age, and the school location. Section B consists of parenting measures. This part of the questionnaire was adopted from parenting styles questionnaire (PSQ) designed and standardized by Utti (2006).

The parenting dimension is divided into 3 parenting measures. Authoritarian, authoritative and laissez-faire. First, authoritarian parenting styles consisting of 8 items, ranging from parental harshness, critical, aggression, neglect, lack of appreciation, unhealthy relationship with the teachers, hard discipline and rigid rules.

The second, authoritative parenting style consisting of 9 items; parents/adolescent healthy relationship, friendliness, positive responses, supervision of class work, encouragement in activities, participation in school activities, encouragement in home work, motivate academic interest, encourage development of social skills, encourage high performance at school.

The third is laissez-faire parenting style consisting of 10 items: parental passiveness, lack of supervision, lack of monitoring, no demanding, lack of active participation in school activities, lack of encouragement in school activities, lack of provision of school materials, parental negligence, and lack of parental assistance in home work.

The scoring was based on the Likert four-point scale of measurement of strongly agree (SA) Agree (A), Disagree (D) and strongly Disagree (SD). The options of the items were weighted in the Likert format with $\mathrm{SA}=4, \mathrm{~A}=3, \mathrm{D}=2$ and $\mathrm{SD}=1$.

1. Authoritarian Parenting: the maximum score a subject could obtain was 32 points, average $=16$ and minimum $=8$ 
respectively. Subjects who scored 16 points and above were considered to have authoritarian parenting background.

2. Authoritative Parenting: the maximum score subjects could obtain was 40 points, average $=20$ and minimum $=10$. Subjects who scored 18 points and above were considered to have authoritative parenting background.

3. Laissez-Faire Parenting: the maximum score subjects could score was 40 points, average $=20$ and minimum $=10$. Subjects who scored 20 points and above were considered to have Laissez-fair parenting background.

\section{Validity and reliability of the instrument}

The instrument used has face and construct validity. Utti (2006) claimed that the face validity was established by experts in test construction in the department of counselling psychology of the Delta State University, Abraka Nigeria. The items were checked for relevance, clarity and whether they were capable of eliciting the right responses and corrections were effected. The Cronbach alpha method was used to establish the construct validity of the instrument. The validity index of $a=.69, \mathrm{P}<0.05$ was obtained. The Cronbach alpha index was suggestive of high internal consistency measure of the construct validity of the instrument.

The split half method was used to establish the stability of the instrument. The researcher employed the Pearson product moment correlation coefficient in establishing the reliability of the instrument. The indices for authoritarian parenting dimension is $\mathrm{r}$ $=.73(\mathrm{P}<.05)$; authoritative parenting $\mathrm{r}=.88(\mathrm{P}<.05)$; and laissez faire is $\mathrm{r}=.73 \mathrm{P}<05$

The section C consists of Adolescents' delinquency scale (ADS) adopted from Iyonsi's (2007) behaviour of delinquency students (BDSS) designed to measure effect of group counselling on the behaviour of delinquent students. The adolescents' delinquency measure consists of 40 items meant to elicit right responses from the participants ranging from truancy, beating junior students, disobedient to school authority, easily irritated, sexual abuse, fighting, rude to teachers, disobedience to parents, membership of secret cult, breaking school properties, disobedient 
to teachers, smoking cigarette or Indian hemp, drug abuse, gambling, stealing, extortion of money, cheating, having friends who drink, getting drunk, enjoy drinking of alcohol, friends who steal, obtaining people properties. There are sexual promiscuity, bullying, absenteeism, loitering around school, punctuality to school, no regard for truth, breaking of school laws, inconsistent in assignment, conscientious with home work etc.

The adolescent delinquency measure was scored based on the Likert four point scale measurement ranging from SA - strongly agree, A = Agree, D - Disagree and SD - strongly disagree. The options on the items were weighted in the Likert format with SA 4; A - 3; D - 2 and SD - 1. The adolescent delinquency measure comprised of 40 items. The Chronbach alpha method was used to establish the construct validity of the instrument. The Cronbach alpha, which is a measure of internal consistency, is indicative of construct validity. The split half method was used to establish the reliability of the instrument. The Pearson product moment correlation coefficient was employed. The reliability alpha level was $r=.74$.

However, school location, gender and age were treated as biodata. The three variables did not go through the process of validation. Hence school location which consisted of urban and rural were scored Urban $=-0$; rural -1 . The gender which is indicative of sex (i.e. male $=0$ female -1 ); and age subdivided into dimensions $12-15=0 ; 16-19=1$.

It should be noted that all participant responses from the 5 rural and 5 urban schools, male or female, 12-15, and 16 - 19 attracted nominal scores which have no marks (Wilson; 2004)

\section{Procedure}

The instrument used for the study comprised adolescent delinquency and parenting styles questionnaire. 450 copies of the questionnaire were produced. Two research assistants were trained and used for the administration of the questionnaire. The research assistants went round the 10 selected secondary schools in Delta Central to distribute the questionnaire. Incentives (i.e. 
pencils, sharpeners, and biros) were introduced for participants' motivational purpose (Barbara, S. E; Kathlen, L. D \& Noami, M. M. 2003).

About 450 copies of the questionnaire were retrieved. 404 copies of the questionnaire were finally scored, analyzed and used for the study.

\section{Results}

Means, standard deviations and inter-correlations were computed for all the measures (Kenny, Blustein, Chaves, Grossman and Gallgher, 2003). The multiple regression analysis was computed on the relationship between the 3 dimensions of parenting styles and adolescent delinquency.

1. Multiple regression analysis on authoritarian parenting and adolescent delinquency produced F-ratio of $.47, \mathrm{df}=1 / 403, \mathrm{P}$ $<05$ level of confidence which was not significant. The result shows that there was no significant relationship between authoritarian parenting styles and adolescent delinquency.

2. Multiple regression analysis on authoritative parenting and adolescent delinquency yielded F- .39, df $-2 / 402, \mathrm{P}<.05$ level of confidence. This is an indication that authoritative parenting style cannot significantly predict adolescent delinquency.

3. Multiple regression analysis on laissez-faire parenting style and adolescent delinquency produced F-value of 2.561, $\mathrm{df}=$ $3 / 401, P>.05$ level of confidence. This is to show that there is significant relationship between laissez-faire parenting style and adolescent delinquency. The $\mathrm{R}^{2}$ and $\mathrm{R}^{2}$ adjusted values of .02 ( $2 \%$ effect size) and .01 ( $1.1 \%$ effect size) is a confirmation to the claim.

4. Multiple regression analysis on school location and adolescent delinquency yielded $\mathrm{F}$ - ratio of $=1.91, \mathrm{df}=5 / 400, \mathrm{P}<.05$ level of confidence. This is an indication that there was no significant relationship between the respondent's school location and adolescent delinquency.

5. Multiple regression analysis on gender of the respondent and adolescents delinquency yielded F-ratio of $=1.62$, df $=5 / 300$, 
$\mathrm{P}<.05$ level of significance. This shows that gender of the respondent cannot significantly predict adolescent delinquency.

6. Multiple regression analysis on age of the respondents and adolescent delinquency revealed $\mathrm{F}=1.37 \mathrm{df}=6 / 398, \mathrm{P}<.05$ level of confidence. The result revealed that there is no significant relationship between age of the respondents and adolescent delinquency.

Parenting Styles: predictor of adolescent delinquency among secondary school students in Delta Central.

Table I. Correlation matrix of Relationship between Parenting Styles and Adolescents Delinquency of Secondary School Students.

\begin{tabular}{|c|c|c|c|c|c|c|c|c|c|}
\hline Variable & 1 & 2 & 3 & 4 & 5 & 6 & 7 & Mean & SD \\
\hline $\begin{array}{l}\text { Adolescent } \\
\text { Delinquency }\end{array}$ & - & 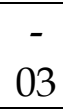 & .03 & $.13^{*}$ & -.00 & .03 & .03 & 1.05 & .23 \\
\hline $\begin{array}{l}\text { Authoritarian } \\
\text { Parenting } \\
\text { Style }\end{array}$ & & - & .06 & -.04 & -.01 & .03 & .05 & 2.36 & .96 \\
\hline $\begin{array}{l}\text { Authoritative } \\
\text { Parenting } \\
\text { Style }\end{array}$ & & & - & -.04 & $.20^{-}$ & $.11^{*}$ & .25 & 2.03 & 1.03 \\
\hline $\begin{array}{l}\text { Laissez-faire } \\
\text { Parenting } \\
\text { Style }\end{array}$ & & & & - & .02 & -.05 & $.13^{*}$ & 3.06 & .93 \\
\hline $\begin{array}{l}\text { School } \\
\text { Location }\end{array}$ & & & & & - & $\begin{array}{c}- \\
.21^{* *}\end{array}$ & -.05 & 1.37 & .48 \\
\hline Gender & & & & & & - & -.05 & 1.48 & .50027 \\
\hline Age & & & & & & & - & 1.49 & .50 \\
\hline
\end{tabular}

Table 1 shows that laissez-faire parenting style has significant relationship with adolescent delinquency. The correlation matrix 
reveals that significant relationship exists between laissez-faire and adolescent delinquency yielding $\mathrm{r}=.13, \mathrm{P}>0.5$ with the mean score of 3.06 and standard deviation of .93, while Authoritarian parenting style has no significant relationship with adolescent delinquency. From the Table I, the combination of authoritative parenting style and location with $\left(\mathrm{r}=-.20^{* *}, \mathrm{P}>0.01\right)$ level of confidence have inverse relationship with adolescent delinquency. Similarly, authoritative parenting style and gender of the respondents with $(\mathrm{r}$ $\left.=.11^{*}, \mathrm{P}>0.05\right)$ level of confidence, $\mathrm{M}=2.03 \mathrm{SD}=1.03$ have relationship with adolescent delinquency.

However, laissez-faire parenting style and age of the respondents with $\left(\mathrm{r}=.13^{*} \mathrm{P}>0.05\right)$ level of confidence, $\mathrm{M}=3.06$, SD $=.93$ have significant relationship with adolescent delinquency. Similarly, location and gender of the respondents with $\left(\mathrm{r}=.-21^{* * *}\right.$, $\mathrm{P}>0.05$ ) level of confidence $\mathrm{M}=1.37$, S.D $=.48$ have inverse relationship with adolescent delinquency. The school location of the respondents (respondents from rural or urban schools) alone has no significant relationship with adolescent delinquency. Moreover, the gender of the respondents (whether the respondent is a male or female) has no significant relationship with the adolescent delinquency.

Table 2 presents the results of the Regression analyses with which the 6 null hypotheses were tested. 
Table 2 Multiple Regression Analysis of Factors Predicting Adolescent Delinquency (Parenting Styles, Location, Gender, Age) of Secondary School Students in Delta Central Senatorial District

\begin{tabular}{llllcccccccc}
\hline \multicolumn{1}{c}{ Source } & Df & Ss & Ms & B & ANOVA & $\mathrm{R}^{2}$ & $\begin{array}{c}\mathrm{R}^{2} \\
\text { Adjusted }\end{array}$ & $\mathrm{F}$ & $\mathrm{P}$ \\
\hline & & & & & SEB & $\mathrm{R}$ & & & & \\
\hline Regression Residual & .1 & .02 & .02 & -8.08 & .01 & .03 & .00 & $=.00$ & .47 & .50 \\
Authoritarian parenting & 403 & 20.78 & 0.5 & & & & & & & \\
Regression & 2 & .04 & .02 & -8.45 & 0.1 & .04 & .00 & -.00 & .39 & .68 \\
& 402 & 20.77 & .05 & & & & & & & \\
Residual & & & & & & & & & & \\
Laissez-Faire & 3 & .39 & .03 & 3.21 & .01 & .14 & .02 & .01 & & 2.55 & $.066^{*}$ \\
Parenting Style & 401 & 20.41 & .05 & & & & & & & \\
Location & 4 & .39 & .01 & -5.28 & 02 & .14 & .02 & .01 & & 1.92 & .11 \\
Gender & 400 & 20.41 & .05 & & & & & & & \\
& 5 & .42 & .08 & 1.63 & .02 & .14 & .02 & .01 & & 1.63 & .15 \\
Age & 399 & 20.39 & .051 & & & & & & & \\
& 6 & .42 & .07 & 6.63 & .02 & .14 & .02 & .01 & & 1.37 & .23 \\
& .308 & 20.38 & .05 & & & & & & & \\
\hline
\end{tabular}

\section{Note:}

1. $\quad \mathrm{B}=$ Regression Coefficient ${ }^{*} \mathrm{P}<.05$ level of significance

2. $\mathrm{SEB}=$ Standard Error of $\mathrm{B}$ 
3. $\mathrm{SS}=$ Sum of Square

4. Dependent Variable - Adolescent Delinquency

5. Predictor $i=$ Authoritarian Parenting Style

ii $=$ Authoritative Parenting style

iii = Laissez-faire Parenting Style

iv. = Location of the respondents

$\mathrm{v} .=$ Gender of the respondents

$\mathrm{vi}=$ Age of the respondents 


\section{Hypothesis I: Table 2a Model I.}

As shown in Table 2 model I the multiple regression analysis computed produced an $\mathrm{F}=47, \mathrm{df}=1 / 403, \mathrm{P}<.05$ level of confidence. The result indicates that authoritarian parenting styles are not a significant predictor of adolescent delinquency. Hence the hypothesis which stated that authoritarian parenting style cannot significantly predict adolescent delinquency was accepted. This was further confirmed by the $\mathrm{R}^{2}$ value which is .001 ( $0 \%$ effect size) and $\mathrm{R}^{2}$ adjusted which is $-.001(0 \%$ effect size $)$. These results were an indication that authoritarian parenting style is not a good predictor of adolescent delinquency.

\section{Hypothesis II: Table 2 Model 2}

As shown in Table 2 the multiple regression analysis computed yielded $\mathrm{F}-=.39, \mathrm{df}=2 / 402, \mathrm{p}<.05$ level of confidence. This is an indication that authoritative parenting style cannot significantly predict adolescent delinquency. Therefore, the null hypothesis which stated that authoritative parenting style cannot predict adolescent delinquency was accepted. The $\mathrm{R}^{2}$ and $\mathrm{R}^{2}$ adjusted values also further confirm this claim.

\section{Hypothesis 3: Table 2 Model 3}

As shown in Table 2 the multiple regression analysis computed produced an $\mathrm{F}=2.55, \mathrm{df}=3 / 401, \mathrm{p}>05$ level of confidence. This is an indication that there is significant relationship between laissezfaire parenting style and adolescent delinquency. Therefore, the null hypothesis which stated that there is no significant relationship between laissez-faire parenting style and adolescent delinquency was rejected. The conclusion was drawn that there was a significant relationship between laissez-fair parenting style and adolescent delinquency. In order to determine the predictive power of these variables, the $\mathrm{R}^{2}$ and $\mathrm{R}^{2}$ adjusted were computed and the values of $.02(2 \%$ contribution) and $.01 \quad(1.1 \%$ of contribution) were obtained respectively. The high proportion of amount of contribution suggests that laissez-fair parenting style significantly predicts adolescent delinquency. As far as this study 
is concerned, the $1.1 \%$ percent effect size is statistically, practically and clinically significant (Kline 2005, P 134; Thompson, 2006, P. 133, 185).

\section{Hypothesis 4: Table 2, Model 4}

As shown in Table 2, the multiple regression analysis computed yielded $\mathrm{F}=1.92$, $\mathrm{df}=4 / 400, \mathrm{P}<.05$ level of confidence. This is an indication that there is no significant relationship between the respondents' school location and adolescent delinquency. Therefore, the hypothesis which stated that the school location, of the respondents cannot significantly predict adolescent delinquency was accepted. The computed $\mathrm{R}^{2}$ and $\mathrm{R}^{2}$ adjusted which yielded values of .02 (2\%) effect size) and .01 (01\%) effect size) was an indication to this claim.

\section{Hypothesis 5: Table 2, Model 5}

As revealed in Table 2, the multiple regression analysis computed shows $\mathrm{F}=1.63$, $\mathrm{df}=5 / 399$. $\mathrm{P}<.05$ level of significance. This shows that gender of the respondents cannot significantly predict adolescent delinquency. Hence, the null hypothesis which stated that gender of the respondents cannot significantly predict adolescent delinquency was accepted. This was further confirmed by computing $\mathrm{R}^{2}$ and $\mathrm{R}^{2}$ adjusted which yielded values of .02 (2\% effect size) and .008 (01\% effect size) respectively.

\section{Hypothesis 6: Table 2, Model 6}

As shown in Table 2, the multiple regression analysis computed produced an $\mathrm{F}=1.37, \mathrm{df}=6 / 308, \mathrm{P}<.05$ level of significance. This is an indication that age of the respondents could not predict adolescents' delinquency. The null hypothesis which stated that age cannot predict adolescent delinquency was accepted. $02 \mathrm{R}^{2}$ and $.01 \mathrm{R}^{2}$ adjusted further confirmed the claim.

Table 3.0 shows the beta analysis of the variables in the equation. 
Table 3 Testing for significance of Regression Coefficient of each Factor as Predictor of Adolescents Delinquency.

\begin{tabular}{|c|c|c|c|c|}
\hline & \multicolumn{4}{|c|}{ Variables in the Equation } \\
\hline Source of Variance & Beta & SEB & t-value & $\mathrm{R}^{2}$ adjusted \\
\hline $\begin{array}{l}\text { Authoritarian parenting } \\
\text { style }\end{array}$ & -.03 & .01 & -.68 & $-.001(0 \%)$ \\
\hline $\begin{array}{l}\text { Authoritative Parenting } \\
\text { style }\end{array}$ & .03 & .01 & .56 & $-.003(0 \%)$ \\
\hline $\begin{array}{l}\text { Laissez-Faire parenting } \\
\text { style }\end{array}$ & .13 & .01 & 2.62 & $.011(1.10 \%)$ \\
\hline $\begin{array}{l}\text { Location of the } \\
\text { respondents }\end{array}$ & .00 & .02 & .08 & $.009(.01 \%)$ \\
\hline $\begin{array}{l}\text { Gender of the } \\
\text { respondents }\end{array}$ & 0.04 & .02 & .71 & $.008(.01 \%)$ \\
\hline Age of the respondents & .02 & .02 & .29 & $.005(.011 \%)$ \\
\hline $\begin{array}{l}\text { Bet } \\
\text { SEB } \\
\mathrm{P}<\text {. }\end{array}$ & $\begin{array}{l}\tan \\
\text { anc }\end{array}$ & $\begin{array}{l}\text { zed } \\
\text { rro } \\
\text { hifi }\end{array}$ & essior & efficient \\
\hline
\end{tabular}

As shown in Table 3, only Laissez-faire parenting styles was found significant with Beta $=.13, \mathrm{df}=3 / 401, \mathrm{t}$-value $=2.62 \mathrm{effect}$ size $=1.10 \% P>.05$. From the table, the result revealed a level of relationship and influence between laissez-fair parenting style and adolescent delinquency.

\section{Discussion}

The study investigated the contributions of the parenting dimensions on the adolescent delinquency.

1. Model 1 shows no significant relationship between authoritarian parenting style and adolescent delinquency. This is an indication that authoritarian parenting style could not significantly predict adolescent delinquency. This finding confirms previous research outcomes; Ang \& Goh (2006) summarized results of some studies on parenting styles to the effect that authoritarian parenting had positive impacts among Asian and Indian adolescents. Similarly, 
Loromeke (2007) in her research stated that African tradition emphasized the use of high control, authority and punishment in bringing the best out of a child. Utti (2006) in her research found that authoritarian parenting style influences adolescents' academic performance positively. On the contrary, parental demanding without responsiveness (authoritarian parenting style) may make adolescents rebellious and delinquent. For instance a home without love, warmth, care, affection but have the parents harsh and aggressive may make the adolescent run away from home, rebellious and have negative associations and other delinquent behaviours follow (Ang, et al 2006; Odebunmi, 2007; Okpako, 2006; Otuadah, 2006; Utti, 2006). Ang \& Goh (2006) reported that authoritarian parenting significantly predicts delinquency among African American adolescents.

2. Model 2 revealed no significant relationship between authoritative parenting style and adolescent delinquency. In a home where the parents provide children's needs, good food, shelter, water, love, warmth, affection, education, control, monitoring, dialogue, etc the children exhibit less delinquent behaviours. Authoritative parenting style is characterized by parental "demandiness" as well as "responsiveness". The dimension of parental form of child rearing is flexible and responsive to child needs but also enforces reasonable standards of conduct (Ang and Goh, 2006). Chen et al (2005); Eke (2004). Otuadah (2006), Umukoro (1997); Wu et al (1998) found in their researches that adolescents who were exposed to higher level of warmth, induction and monitoring would less likely to be delinquents. According to Ang \& Goh (2006); Utti (2006), adolescents whose parents are demanding and responsive perform better in social competence than children from authoritarian background.

3. Model 3: shows significant relationship between laissez-faire parenting style and adolescents delinquency. This is an indication that the dimension of parenting style predicts adolescents' delinquency. This finding is consistently in 
support of some researches carried out previously: Utti (2006) reported that Laissez-faire parenting dimension is without well defined or clear-cut goals and such parents play passive role in the rearing of children. Ang et al claim that laissez-faire parents are those who impose few restrictions, rules or limits on their children. Kring et al (2007) reported a clinical case of 19 year adolescent from typical dysfunction parenting background who prolonged into delinquent activities because of poor parenting dimension. Growing a child with loose hands is the worst offence parents can engage in. The dimension of this parenting accommodates parental responsiveness to the children needs without demandingness. Such child from that kind of background becomes wild, delinquent and maladjusted to himself, family and society at large. Laissezfaire parenting enhances the exhibition of delinquent behaviours among adolescents.

4. Model 4: revealed that there is no significant relationship between school location and adolescent delinquency. This is an indication that school location cannot predict adolescent delinquency. Considering the fact that the whole wide world is a small global village, adolescents from urban schools may not behave differently from those in the rural setting. This finding is contrary to the finding of Eke, 2004. She is of the view that environment may play significant role in the adolescent delinquency.

5. Model 5: shows no significant relationship between gender and adolescent delinquency. This finding shows that gender of the respondents cannot significantly predict adolescent delinquency. Some researches had shown that gender (i.e. whether male or female) is not a significant factor in adolescents' deviant behaviour (Onyechi and Okere, 2007). Mallum, Haggai and Ajaegbu (1999), and Wu et al (1998) in their researches found that there was no significant difference in delinquency between the two categories (males and female). On the contrary, Bingham et al (2006) observed 
that men had greater number of offences than women over all. Similarly, it was reported that boys with poor parental background may become school dropout, who may later graduate into street boys, bus conductors or touts (area boys') found in uncompleted buildings, bridges, motor parks etc (Okpako, 2004; Otuadah, (2006).Sekuk, Rimfat \& Ogbonna (2003) noted that until recently male adolescents were by far more involved in delinquent acts than female. But times have changed more and more females are now getting involved in delinquent activities.

6. Model 6: shows no significant relationship between age of respondents and adolescent delinquency. Age cannot significantly predict adolescent delinquency. It should be noted that there is a huge variation in age factor of adolescents from one society to another. However, age is not determined by the society (Okpako, 2004), but rather by biological compositions (Ezeh, 2005). He noted that the biological changes are the driving forces behind all adolescents' behaviour. Wu et al (1998) found that with increase in age of participants there was increase in the rate of delinquency. They noted that as the adolescent grows older he or she had some courage to try out new things even more criminal things and rebellious nature also increases. It was also found that delinquency of age group 15 differ significantly from those in age groups 12, 13, 14 and above 16 were about the same.

\section{Implications for Counselling/Conclusion}

The study has a lot of practical and clinical implications on parental counselling and child rearing practices. Laissez-faire parenting dimension influences adolescent delinquency. Parental demand ness and responsiveness play crucial role in adequate parenting of adolescent. Sufficient time must be created by parents (especially mothers) to stay with children at home. Adequate monitoring, control, supervision irrespective of the gender, school location and age are paramount factors in positive and effective child rearing. Adequate parental love, warmth, care, attention are factors for 
effective parenting. Dialogue, communication, explanations and establishment of good and cordial relationships between parents and adolescents could enhance positive and effective parenting. Creation of suitable environment for child rearing and provision of the child needs may prevent adolescents' delinquency. Parental over reaction to issues, harsh environment and parental aggression may make adolescents take to the streets and prong adolescents into delinquent behaviours.

\section{References}

Akinson, K. (2004); Family Influences on peer Relationships Divorce and

Teens: A Disruptive Tale: http/inside.Bard.edu/academic/ specialproj/clarliog/bullying/group5 divorce.htm?

American Indian Adolescents in Substance Abuse Treatment:

Diagnostic Status (2000). Iournal of Substance Abuse Treatment 30 (4), 275-289.

Ang, R. P. \& Goh, Dion H. (2006) Authoritarian parenting Style in Asian Societies: A Cluster - analytic Investigation. Contemporary Family Therapy: An international Journal. 28 (1) pp. $132-151$.

Barbara, S. E; Kathlen L. D. and Noami, M. M. (2003) Motivational Attributes of Occupational Possible Selves for Low Income Rural Women. Journal of Counselling Psychology: 50 (2), 156 - 164)

Barnes, H. \& Olson, D. H. (1992) Parent-Adolescent Communication. In H. I. McCubbin, H. Barnes A. Larsen, M. Muxen, \& M. Wilson (Ed), Family Inventories (2nd ed.; pp 29 4). St. Paul, MN. Family Social Science.

Bingham, Raymond C; Shope, Jean T \& Raghunathan Trivellore (2006) Patterns of Traffic Offenses from Adolescent Licensure into Early Young Adulthood. 39, 35 -42.

Boroffice, O. B. (2003) Recreation and Health Behaviour of Adolescents. In Contemporary Issues and Researches on Adolescents (Edited by I. A. Nwanuoke, O. Bampgbose \& O. A. Moronkola). Ibadan (Omoade Printing Press) pp 110 - 126. Brunstein, J. C. \& Gollwiter, P. M. (1996) Effects of Failure on Subsequent Performance; The Importance of Self-Defining 
Goals: Lournal of personality and Social Psychology. 70 (2), 395 407.

Baumrind, D. (1991). The influence of parenting style on adolescent competence and substance use. Journal of Early Adolescence, 11 (1), 56 - 95.

Chen, Yi-Fu \& Wu Chi-in The Dynamic Relationships Between Parenting and Adolescent Delinquency: A Group - Based Model Approach. www.edu/tu/grdcrim/temp

Darling (2007) Parenting style and its correlates. www.w.9thealt.com/practioner/ceduc/parentingstyles/.htm

Duchesne, S., Ratelle, C. F., Larose, S. \& Guay, F. (2007). Adjustment Trajectories in College Science Programs: Perceptions of Qualities of parents' College Teachers' Relationship. Journal of Counselling psychology 54 (19), 6271.

Edwards, L. M. \& Shane, J. L. (2006). Family Support, Acculturation, and Life Satisfaction in Mexican - American youth. A mixed-Methods Exploration. Journal of Counselling Psychology 53 (3), 279 - 287.

Eke, E. (2004) Facing New Challenges in Adolescence, Enugu, E. L. Demak (Publishers).

Eke, E. (2004a) Juvenile Delinquency in Nigerian Enugu, Eli Demak (Publishers).

Ekoja, O. C. and Adole, G. M (2008) Rural Youth Extension programme and Counselling as Means of Eradicating Gang Delinquency in Youths in Nigeria. The Nigerian Educational Psychologist: Journal of the Nigeria Society for Educational Psychologists (NISEP) 6; $107-113$.

Ezeh C. O. (2005) Adolescent Psychology Enugu, Computer Edge Publishers.

Green, Thomas L. (1997) Psychology of Adjustment, New Jersey, Prentice Hall.

Hyssong, A (2000): Perceived Peer Context and Adolescent Adjustment. Journal of Research on Adolescent (10) $291=211$. Inman A. G., Howard, E. E., Beaumont, R. L , Waker, J. A. (2007) Cultural Transmission: Influence of Contextual Factors in 
Asian Indian Immigrant Parents' Experiences: Journal of Counselling Psychology; 54 (1) 93 - 100.

Iyonsi, P.H. Lomena (2007) Effect of Group Counselling on the Behaviour of Delinquent Students in Sapele Local Government Area. Unpublished, Master Dissertation proposal of Delta State University, Abraka.

Kenny, M. E.; Blustein, D. L.; Chaves, A Grossman J. M. \& Gallagher, L. A. (2003). The Role of Perceived Barriers and Relational Support in the Educational and Vocational Lives of Urban High School Students. Journal of Counselling Psychology. 50 (2), 142 - 155.

Kline, Rex. B. (2005) Beyond Significance Testing: Reforming Data Analysis Methods in Behavioural Research. Washington DC. APA.

Knox, M. S. (1997). The possible Selves of Adolescents. Unpublished Doctoral Dissertation, University of Toledo, Ohio

Kring A. M. Dvaison G. C. Neale, J. M \& Johnson S. L. (2007). Abnormal Psychology (10 th Edition) New York (John Wiley \& Sons, Inc).

Legault Lisa; Green-Demers Isabella \& Relleties Luc (2006) Why do High School Students Lack Motivation in the Classroom? Toward an Understanding of Academic A motivation and the Role of Social Support. Journal of Educational Psychology, 98 (3) $567-482$.

Loromeke, C. JK. (2007). Relationship Among parenting Styles, Self-Concept and Students Career Dispositions in Uvwie Local Govt. Area of Delta State. Unpublished M.Ed Thesis of Delta State University, Abraka.

Mallum, T. O. Haggai, M. P. \& Ajaegbu, K. J. U. (1999). An Introduction to Child Development. Jos; Deka Publications.

Odebunmi, A. (2007). Parenting: A Cross-Cultural and Psychological Perspective, Abuja, (Afabunmi Nigeria Limited) Okorodudu, G. N (2006) Efficacy of Recreational Exercises and Rational Emotive Behavioural Therapies for Adolescent Stress 
Management. Perspective in Education; international Research and Development. 22 (3); pp 172 - 185.

Okorodudu, R. I. and Okorodudu G. N (2003) An Overview of Conduct Problems of the Nigeria Child. Online Publications by the World Forum on Childcare and Education, AcapulcoMexico Website: http://www.ied/edu.hk/cric/new/apjted/ index.htm

Okorodudu, G. N. and Omoni, G. E. (2005) Child Abuse \& Parental Neglect: A Cog in the Wheel of Development in Nigeria. Delsu Journal of Educational Research and Development 4(1) $125-135$.

Okorodudu, R. I. and Okorodudu G. N (2003d) Causes of Behaviour problems among Adolescents. The Nigerian Educational Psychologist. Journal of Nigerian Society for Educational Psychologists (NISEP) 2 (1) 73 - 81

Okpako, J. E. F (2004) Parenting the Nigerian Adolescents Towards

Smooth Transition to Adulthood. In Contemporary Issue and Research in Adolescents (I. A. Nwazuoke; O. Bamgbose \& O. A. Morokola (Ed) Ibadan Omoade Printing Press pp 275 - 288. Onyehalu, A. S. (2003). Juvenile Delinquency: Trend, Causes and Control Measures, The Behaviour Problem of the Nigerian Child: A Publication of The Nigerian Society for Educational Psychologists (NISEP), 12 - 19.

Onyewadime, M. A (2004) Parents, Involvement of Housemaid in Home Reading in an African Setting: Current Trends and Implications (I.A. Nwazuoke, O. Bamgbose \& O. A. Morokola Ed). Ibadan Omoade Printing Press pp. 247 - 354.

Otuadah, C. E. (2006) Parental Behaviour and Peer Group Influence as Correlates of Delinquent Behaviour among Secondary School Students in Warri Metropolis. Unpublished M.Ed Thesis of Delsu, Abraka

Sekuk, R. T. Rimfat, D. Z and Ogbonna B. B (2003). Prevalence of Delinquent Behaviour among Adolescents: Implications for Counselling. The Behaviour problems of the Nigeria Child. A Publication of the Nigerian Society for Educational Psychologists (NISEP) Edited by R. Onwukwe Nnachi \& P. S. E. Ezeh pp. $59-68$ 
Stanford University News Service (415) 723-2558: Parenting Styles may influence teens' ethnic identity. www.images@newsservice.stanford.edu.

Trivellor, Onyechi, K. C. \& Okere, A. U. (2007) Deviant Behaviour as Correlate of Academic Achievement Among Secondary School Adolescents: Implication for Counselling In Optimization of Service Delivery in the Education Sector: Issues and Strategies (B. G. Nworgu Ed) 105 - 110

Thompson, B. (2006). Foundations of Behavioural Statistics: An Insight-Based Approach. New York: Guilford Publications Inter.

Ukoha, E. K. (2003) Self-Concept and Cult Activity Tendencies Among Secondary School Adolescent Students in Abia State in the Behaviour problems of the Nigerian Child. $\underline{A}$ Publication of the Nigerian Society for Educational Psychologists (NISAEP) R. Onwukwe Nnachi and P. S. E. Ezeh Edited pp 103 - 116.

Utti, Alice (2006) Relationship Between Parenting Styles and Students' Academic Achievement in Secondary Schools in Ethiope East L. G. A of Delta State. Unpublished M. Ed Thesis of Delta State University, Abraka.

Wilson, I. H. (2005). Essential Statistics. New Jersey: Pearson Education Inc.

Wu , Chia , Lee Shin Yng and Lee Yuch Wun: (1998) Factors Affecting Adolescent Delinquency in Singapore www.3.ntu.edu.sg/nbs/sabre/working-paper 